\title{
Composition and Immunochemical Properties of the Cell Surface Proteins of Vibrio cholerae
}

\author{
By SHAHJAHAN KABIR \\ Department of Biochemistry, The State University of Groningen, Groningen, and the National \\ Institute of Public Health, Bilthoven, The Netherlands
}

(Received 22 November 1985; revised 27 February 1986)

\begin{abstract}
The composition and immunochemical properties of cell surface proteins of Vibrio cholerae belonging to both the biotypes (classical and $\mathrm{El} \mathrm{Tor)} \mathrm{and} \mathrm{the} \mathrm{serotypes} \mathrm{(Ogawa} \mathrm{and} \mathrm{Inaba)} \mathrm{were}$ investigated. Proteins were isolated by extraction with EDTA/ $\mathrm{NaCl}$. When the extract was further treated with sodium deoxycholate, a product significantly enriched with the major protein was obtained. The surface localization of these proteins was confirmed by immunoelectron microscopy using protein $\mathrm{A}$-colloidal gold particles as probes. Antisera to these proteins $(a)$ possessed complement-mediated bactericidal activities towards $V$. cholerae strains belonging to both the biotypes and the serotypes, and $(b)$ upon crossed immunoelectrophoresis produced several immunoprecipitation reactions towards whole-cell sonicates belonging to all types of $V$. cholerae. These proteins were immunogenic in the rabbit intestine, as antibodies of two classes ( $\operatorname{IgG}$ and $\operatorname{IgA}$ ) were detected in the intestinal fluids. The intestinal immune response was greatly enhanced when cell surface proteins were administered with liposomes. These results suggest that cell surface proteins represent common antigens of $V$. cholerae and can be explored as vaccine candidates against cholera.
\end{abstract}

\section{INTRODUCTION}

Vibrio cholerae, the causative agent of cholera, colonizes the small intestine, where it secretes an exotoxin which binds to the mucosal epithelial cell and activates the adenylate cyclase system. This process alters ion transport at the mucosal surface and finally causes diarrhoea (Field, 1971). Although both antitoxic and antibacterial immunities are developed in the cholera patient (Majumdar et al., 1981), volunteer studies have demonstrated that the predominant operative immune mechanism is antibacterial rather than antitoxic in nature (Levine et al., 1979).

$V$. cholerae has two major serotypes (Ogawa and Inaba) and two biotypes (classical and El Tor). Its cell surface, like that of other Gram-negative bacteria, contains both lipopolysaccharides (LPS) and proteins which are immunogenic in both humans and experimental animals (Majumdar et al., 1981; Kabir, 1983a, b). Whereas antibody to the LPS is specific for the serotype, antibodies to the cell surface proteins react with $V$. cholerae strains irrespective of their serotypes and biotypes (Kabir, 1980, 1983a,b). V. cholerae LPS possesses endotoxic properties (Kabir, 1982), but the cell surface proteins lack toxic properties (Kabir \& Mann, 1980). The cell surface proteins could thus be developed as a potential non-pyrogenic vaccine candidate against cholera.

Several new techniques have become available to investigate the localization and antigenicity of bacterial proteins. Electron microscopic techniques using colloidal gold particles of varying sizes coupled to protein A have been used to localize surface antigens (Roth, 1982). Crossed

Present address: Tobaksspinnargatan 5, 11736 Stockholm, Sweden.

Abbreviations: CIE, crossed immunoelectrophoresis; DOC, sodium deoxycholate. 
immunoelectrophoresis has been used to obtain fingerprinting patterns of antigenic proteins (Axelsen, 1973). However, none of these techniques has been used to analyse the immunochemical properties of the cell surface of $V$. cholerae. As little work has been done on the immunogenicity of these proteins in intestinal fluids, the present investigation was initiated to obtain more information on the localization and immunochemical properties of cell surface proteins of $V$. cholerae.

\section{METHODS}

Bacterial strains and growth conditions. Vibrio cholerae strains 395 (Ogawa, classical), 569B (Inaba, classical), W13021 (Ogawa, El Tor) and N-16961 (Inaba, El Tor) were used. Cultures were grown in 3\% (w/v) peptone/water with continuous shaking at $37^{\circ} \mathrm{C}$ and harvested at the stationary phase of growth $(12 \mathrm{~h})$.

Extraction of cell surface proteins of $V$. cholerae. A $10 \mathrm{~g}$ (wet weight) sample of $V$. cholerae 395 was washed twice with cold EDTA/ $\mathrm{NaCl}(25 \mathrm{ml}, 0.12 \mathrm{M}$-EDTA, $0.77 \mathrm{M}-\mathrm{NaCl}, \mathrm{pH} 7.2)$. The combined extracts obtained after centrifugation $(20000 \mathrm{~g}, 30 \mathrm{~min})$ were concentrated by negative pressure dialysis against $0 \cdot 01 \mathrm{M}$-phosphatebuffered saline (PBS, pH 7.2) and again centrifuged for $15 \mathrm{~min}$. The resulting supernate was used for further investigation. A portion of the supernate was lyophilized. The material $(35 \mathrm{mg})$ was treated with sodium deoxycholate (DOC; $0.5 \%, 5 \mathrm{ml}$ ) for $16 \mathrm{~h}$ at room temperature and centrifuged at $85000 \mathrm{~g}$ for $1 \mathrm{~h}$. The pellet was taken up in water $(5 \mathrm{ml})$. Both the pellet suspension and the supernate were dialysed extensively against water for $24 \mathrm{~h}$ and lyophilized. The dry weights of the pellet and supernate were $7 \mathrm{mg}$ and $24 \mathrm{mg}$, respectively.

Isolation of LPS. V. cholerae 395 (Ogawa) LPS was prepared by the phenol/water procedure (Westphal et al., 1952). The crude LPS was further purified by repeated ultracentrifugation at $105000 \mathrm{~g}$ (Westphal \& Jann, 1965). The protein content was measured by the Lowry method, using bovine serum albumin as the standard.

Preparation of antisera. Antisera against whole cells were raised in rabbits by injecting $V$. cholerae cells $\left(10^{9}\right)$ suspended in Freund's complete adjuvant (Difco) intramuscularly on days 0, 14, 28 and 42. Blood was collected 1 week after the last immunization.

Antisera against cell surface proteins were prepared with injection mixtures containing $1 \mathrm{mg}$ in Freund's complete adjuvant. Rabbits were immunized as described above. Antisera were stored at $-70^{\circ} \mathrm{C}$ until use.

Antisera against the major surface protein were prepared as described by Kabir $(1983 a)$. Briefly, cell surface proteins were separated by SDS-PAGE. The section of the gel containing the major protein band having approximate molecular mass $48 \mathrm{kDa}$ was cut into slices and eluted by shaking at $37^{\circ} \mathrm{C}$ for $12 \mathrm{~h}$ with $\mathrm{NH}_{4} \mathrm{HCO}_{3}$ containing $1 \% \mathrm{SDS}$. After extensive dialysis against $0.05 \mathrm{M}-\mathrm{NH}_{4} \mathrm{HCO}_{3}$, the extract was lyophilized. The protein ( $100 \mu \mathrm{g}$ in 0.25 ml PBS, pH 7.2) was mixed with an equal volume of Freund's complete adjuvant (Difco). A sample of the emulsion $(0.2 \mathrm{ml})$ was injected directly into the popliteal lymph nodes of rabbits. A booster dose was given on day 14, and the rabbits were bled 1 week later. The immunoglobulins were isolated by precipitation of the immune serum with ammonium sulphate to a final saturation of $33 \%$.

Absorption of serum with LPS. To remove immunoglobulins against the serotype Ogawa LPS, the antiserum $(1 \mathrm{ml})$ was treated with LPS $\left(1 \mathrm{mg}\right.$ ) from $V$. cholerae 395 (Ogawa) overnight at $4{ }^{\circ} \mathrm{C}$. The LPS-absorbed antiserum was centrifuged at $105000 \mathrm{~g}$ for $4 \mathrm{~h}$. To monitor the removal of anti-LPS antibody, the absorbed sera were immunoprecipitated with $V$. cholerae LPS. Absorbed sera were stored at $-70^{\circ} \mathrm{C}$ until use.

Immunoelectron microscopic detection of proteins of $V$. cholerae at the cell surface. Gold particles (mean diameter $16 \mathrm{~nm}$ ) were used as electron-dense immunolabels and were prepared according to the procedure of Slot \& Geuze (1981). Briefly, chloroauric acid $\left(\mathrm{HAuCl}_{4}\right)$ was reduced with sodium citrate and the particles were adsorbed with protein A (Pharmacia) to produce a stable colloidal suspension of protein A-gold complex. This was centrifuged at $15000 \mathrm{~g}$ for $45 \mathrm{~min}$ and washed once with PBS $(0.01 \mathrm{M}, \mathrm{pH} 7 \cdot 2)$. The complex was suspended in a small volume of PBS and stored in $50 \%(\mathrm{v} / \mathrm{v})$ glycerol at -15 to $-20{ }^{\circ} \mathrm{C}$. Before use the probe was centrifuged for $5 \mathrm{~min}$ in an Eppendorf centrifuge to remove any aggregates formed during storage.

Heat-inactivated anti-cell surface protein $\mathrm{IgG}\left(100 \mu 1,15 \mathrm{mg} \mathrm{ml}^{-1}\right)$ was added to a suspension of $V$. cholerae cells $\left(2 \times 10^{8}\right)$, pre-fixed with $0.02 \% \mathrm{OsO}_{4}$. After incubation for $1 \mathrm{~h}$ at room temperature, the cell suspension was centrifuged and the pellet was washed three times, each time with $0.2 \mathrm{ml}$ PBS. The cell pellet was taken up in $0.5 \mathrm{ml}$ PBS and $30 \mu \mathrm{l}$ protein A-gold complex was added. After incubation for $1 \mathrm{~h}$ at room temperature, the cell suspension was centrifuged at $10000 \mathrm{~g}$. The pellet was washed three times with PBS.

Control experiments with pre-immune rabbit $\mathrm{IgG}$ were done as described above.

Crossed immunoelectrophoresis $(C I E)$. This was done with an intermediate gel as described by Weeke (1973). Briefly, $10 \mathrm{ml}$ of the hot agarose (1\%) containing $1 \%$ polyethylene glycol (PEG) 6000 was poured on a prewarmed glass plate $(8 \times 12 \times 0.1 \mathrm{~cm})$ placed on a horizontal table. $V$. cholerae sonicates $(7 \mu \mathrm{l})$ were applied to a well $(3 \mathrm{~mm}$ diameter). Electrophoresis was done at $10 \mathrm{~V} \mathrm{~cm}^{-1}$ on the gel plate. Electrophoresis in the first dimension was stopped when the indicator dye reached the end of the gel plate. A strip of the gel containing the test material $(1.8 \times 8 \times 0.1 \mathrm{~cm})$ was placed on the hydrophilic side of the gel bond film (Marine Colloids). An intermediate gel $(2 \times 8 \times 0.1 \mathrm{~cm})$ without antibody was interposed between the first and second dimension gel. An agarose 
solution $(1 \%, 4 \mathrm{ml})$ containing $0 \cdot 25 \mu \mathrm{l}$ of the immune sera was placed on the remainder of the gel. Electrophoresis

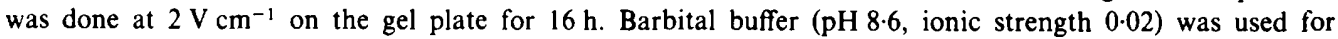
electrophoresis. The gels were washed, dried and processed as described by Weeke (1973).

Bacterial agglutination. Cultures were adjusted to $10^{10}$ cells $\mathrm{ml}^{-1}$ in $0.2 \mathrm{M}-\mathrm{PBS}(\mathrm{pH} \mathrm{7.2)}$. Twofold dilutions of antisera to the cell surface proteins of $V$. cholerae were added to an equal volume of bacteria in microtitre plates. Before addition, the antisera were inactivated by incubating in a water bath at $56^{\circ} \mathrm{C}$ for $30 \mathrm{~min}$. The agglutination pattern was recorded after incubation for $2 \mathrm{~h}$ at room temperature.

Serum vibriocidal assay. Serial fivefold dilutions of the serum (heat inactivated) were made in a $0.5 \mathrm{ml}$ volume containing $0.4 \mathrm{ml}$ fresh guinea pig complement ( $1: 20$ dilutions). To each dilution was added $0.45 \mathrm{ml}$ bacterial suspension containing $2 \times 10^{3}$ viable cells $\mathrm{ml}^{-1}$. The mixture was placed in a water bath at $37^{\circ} \mathrm{C}$ for $1 \mathrm{~h}$ and then on a nutrient agar plate. Colonies of $V$. cholerae were counted after overnight incubation at $37^{\circ} \mathrm{C}$. The vibriocidal titre was determined as the dilution of the serum causing $50 \%$ inhibition of bacterial growth.

Collection of intestinal washings. Rabbits were starved, but were allowed to drink water, for $24 \mathrm{~h}$. A portion of the intestine, from the end of the stomach to the junction of the ileum and caecum, was isolated and cut into small portions. The lumen was washed with cold PBS $(0.01 \mathrm{M}, \mathrm{pH} 7 \cdot 2)$ three times. The combined washings were made up to $200 \mathrm{ml}$ and centrifuged at $3000 \mathrm{~g}$ for $30 \mathrm{~min}$. The supernate was sonicated in a Braunsonic sonicator for $10 \mathrm{~min}$. The material was concentrated 20 -fold by dialysis against PEG $6000\left(40 \%\right.$, w/v) and stored at $-20^{\circ} \mathrm{C}$ until use. Phenylmethylsulphonyl fluoride (PMSF, Boehringer-Mannheim), a protease inhibitor, was added to the washings to a final concentration of $2 \mathrm{mM}$.

$E L I S A$. Antibody titres in intestinal washings to cell surface proteins were determined by ELISA in microtitre plates as described previously (Kabir, 1983b). Briefly, individual wells of ELISA plates were coated with $100 \mu 1$ cell surface proteins $\left(50 \mu \mathrm{g} \mathrm{ml}^{-1}\right)$ suspended in $0.1 \mathrm{M}-\mathrm{NaHCO}_{3}(\mathrm{pH} \mathrm{9.6)}$. After incubation for $16 \mathrm{~h}$ at room temperature, the antigen was discarded and the wells were washed with $0.01 \mathrm{M}-\mathrm{PBS}, \mathrm{pH} 7 \cdot 4$, containing $0.05 \%$ $(\mathrm{v} / \mathrm{v})$ Tween 20 (PBST). Fivefold dilutions of the test material (intestinal wash) were added to the antigen-coated wells and incubated at $37^{\circ} \mathrm{C}$ for $2 \mathrm{~h}$. After washing, the wells were filled with a sheep anti-rabbit immunoglobulin conjugated with peroxidase (specific for rabbit $\operatorname{IgA}$ ) and incubated at $37^{\circ} \mathrm{C}$ for $2 \mathrm{~h}$. The plates were then washed and further incubated for $10 \mathrm{~min}$ with the substrate (tetramethylbenzidine in dimethylsulphoxide and hydrogen peroxide). The reaction was stopped by the addition of $\mathrm{H}_{2} \mathrm{SO}_{4}(0.5 \mathrm{M})$ and the $A_{450}$ was measured by a Titertek Multiskan automatic plate reader (Flow Laboratories).

Preparation of liposomes. Negatively charged liposomes containing cell surface proteins were prepared according to the procedure of van Rooijen \& van Nieuwmegen (1980). Briefly, egg lecithin (6 mg), cholesterol $(1 \mathrm{mg})$ and phosphatidic acid $(1 \mathrm{mg})$ were dissolved in chloroform $(1 \mathrm{ml})$ in a $100 \mathrm{ml}$ round-bottomed flask. The thin film formed after evaporation at $37^{\circ} \mathrm{C}$ was dispersed by gentle shaking for $10 \mathrm{~min}$ in $2 \mathrm{ml} 0.1 \mathrm{M}$-sodium phosphate buffer, $\mathrm{pH} 7 \cdot 2$, with $25 \mathrm{mg}$ cell surface proteins. The suspension was kept at room temperature for another $2 \mathrm{~h}$ and then sonicated for $45 \mathrm{~s}$ at $4{ }^{\circ} \mathrm{C}$ in a Braunsonic sonicator and kept at room temperature for $2 \mathrm{~h}$. The protein-containing liposomes were separated from non-entrapped proteins by passage through a Sepharose $4 \mathrm{~B}$ column $(1.5 \times 30 \mathrm{~cm})$ equilibrated with $0.15 \mathrm{M}-\mathrm{PBS}, \mathrm{pH} 7.2$. Protein-containing liposomes were eluted in the void volume and centrifuged at $100000 \mathrm{~g}$ for $1 \mathrm{~h}$. The final pellet was resuspended in PBS and kept at $4{ }^{\circ} \mathrm{C}$.

\section{RESULTS}

\section{Composition of EDTA-extracted material of V. cholerae}

Extraction of $V$. cholerae cells with EDTA/ $\mathrm{NaCl}$ did not cause any detectable cell lysis when monitored by electron microscopy. The composition of the EDTA-extracted material, which was predominantly protein $(90 \%$ by weight $)$, was examined by SDS-PAGE. The extract was resolved into a large number of proteins; one of the major components had an approximate molecular mass of $48 \mathrm{kDa}$ (Fig. $1 \mathrm{c}$ ); other prominent protein bands of approximate molecular masses $66,25,20$ and $13 \mathrm{kDa}$ were observed.

\section{Treatment of EDTA-extracted material with DOC}

EDTA-extracted material was treated with DOC, and both the DOC-soluble materials and the insoluble pellet were analysed by SDS-PAGE (Fig. 1). DOC preferentially solubilized a few proteins. Among these, the bands at 66 and $20 \mathrm{kDa}$ were prominent (Fig. la). The pellet was significantly enriched with the major protein of molecular mass $48 \mathrm{kDa}$ (Fig. $1 \mathrm{~b}$ ). The protein band at $25 \mathrm{kDa}$ was also enriched, as very little of it had appeared in the supernatant. 
(a)

Mol.

mass

(kDa)

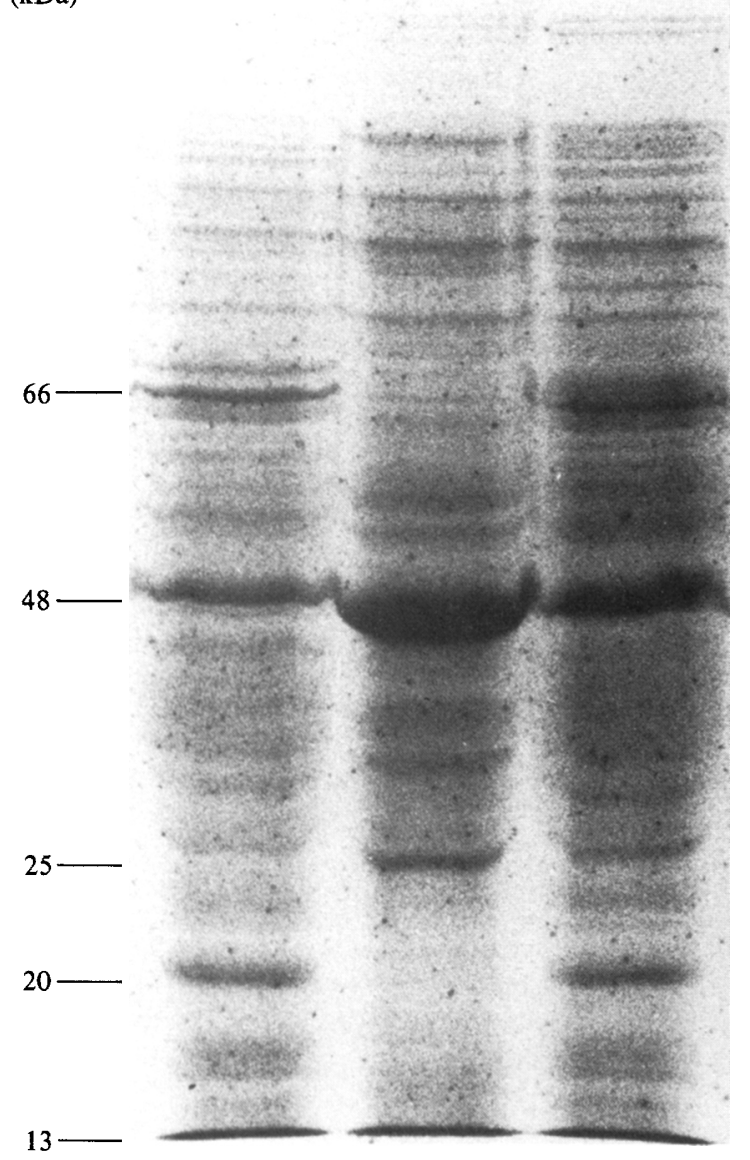

(b) (c)
Fig. 1. Analysis of the cell surface proteins of $V$. cholerae 395 (Ogawa, classical). Cell surface proteins $(35 \mathrm{mg})$, obtained by EDTA/ $\mathrm{NaCl}$ extraction of $V$. cholerae 395 cells, were further treated with DOC $(0.5 \% ; 5 \mathrm{ml})$ for $16 \mathrm{~h}$ at room temperature and centrifuged at $85000 \mathrm{~g}$ for $1 \mathrm{~h}$. Tracks: (a) DOC-soluble proteins; (b) DOCinsoluble pellet; (c) EDTA/ $\mathrm{NaCl}$ extracted proteins. SDS-PAGE was done by the procedure of King \& Laemmli (1971). Briefly, the gel $(10 \%$, w/v acrylamide) was cast between glass plates $(15 \times 15 \mathrm{~cm})$ to a height of $10 \mathrm{~cm}$, using spacers $1.5 \mathrm{~cm}$ thick. A stacking gel $(3 \%, \mathrm{w} / \mathrm{v}$, acrylamide) $2 \mathrm{~cm}$ high was applied to top of the analytical gel. Electrophoresis was done at $30 \mathrm{~mA}$. Bovine serum albumin ( $68 \mathrm{kDa})$, ovalbu$\min (45 \mathrm{kDa})$ and cytochrome $c(11.7 \mathrm{kDa})$ were used as marker proteins.

\section{Surface localization of EDTA-extracted proteins by immunoelectron microscopy}

To determine whether the EDTA-extracted proteins were exposed on the cell surface of $V$. cholerae, immunoelectron microscopic techniques were applied. The LPS-absorbed antiserum was incubated with $V$. cholerae 395 cells and then labelled with protein A-gold particles. Black dots representing gold particles were distributed over the cell surface (Fig. $2 a$ ). $V$. cholerae cells incubated with the pre-immune sera and later treated with protein A-gold particles did not react.

$V$. cholerae N-16961 (Inaba, El Tor) cells were also incubated with the LPS-absorbed antisera to the cell surface proteins, obtained from $V$. cholerae 395 (Ogawa, classical). Gold particles were distributed on the heterologous strain (Fig. 2b), suggesting that surface proteins from the Ogawa strain (classical) bear antigenic similarity to those from a heterologous strain (Inaba, El Tor).

Since the $48 \mathrm{kDa}$ protein appeared to be a major protein (Fig. 1), its surface localization was determined by the immunoelectron microscopic technique. The antisera to the $48 \mathrm{kDa}$ protein were absorbed with the homologous LPS. $V$. cholerae 395 (Ogawa, classical) cells were incubated with the LPS-absorbed antiserum to the $48 \mathrm{kDa}$ protein. Gold particles were detected on the cell surface (Fig. $2 c$ ), indicating that this protein was exposed on the cell surface. To determine whether the $48 \mathrm{kDa}$ protein represented one of the common antigens of $V$. cholerae, a 

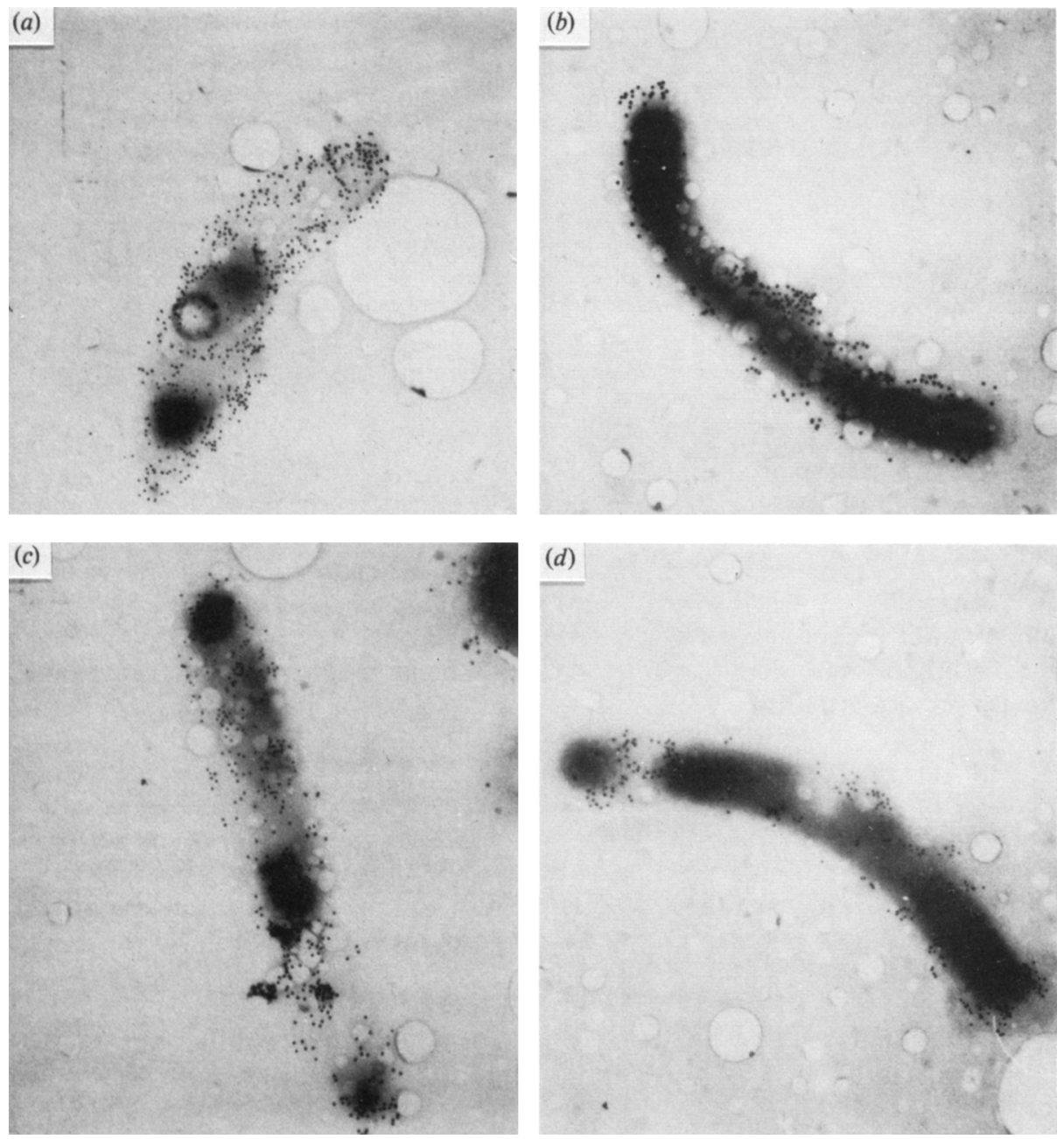

Fig. 2. Visualization of the cell surface proteins of $V$. cholerae by immunoelectron microscopy using protein $\mathrm{A}$-gold particles as probes. $V$. cholerae cells $\left(2 \times 10^{8}\right)$, belonging to different biotypes and serotypes, were incubated with antisera to proteins obtained from $V$. cholerae 395 . Afterwards protein A-gold (16 nm diameter) probes were added. (a) Homologous $V$. cholerae 395 (Ogawa, classical) cells incubated with the LPS (Ogawa)-absorbed antisera to the EDTA extracted proteins from $V$. cholerae 395 cells. (b) Heterologous $V$. cholerae N-16961 (Inaba, El Tor) incubated with the LPS (Ogawa)absorbed antisera to the EDTA proteins from $V$. cholerae 395 cells. (c) Homologous $V$. cholerae 395 (Ogawa, classical) incubated with the LPS (Ogawa)-absorbed antisera to the $48 \mathrm{kDa}$ protein. $(d)$ Heterologous $V$. cholerae $\mathrm{N}-16961$ (Inaba, El Tor) incubated with the antisera to the $48 \mathrm{kDa}$ protein. Magnification $\times 37500$.

heterologous $V$. cholerae strain (N-16961, Inaba, El Tor) was incubated with the LPS-absorbed antiserum from $V$. cholerae 395 . This protein was also on the cell surface (Fig. $2 d$ ), suggesting that the $48 \mathrm{kDa}$ protein was one of the major common antigens of $V$. cholerae.

\section{Crossed immunoelectrophoresis}

To determine whether the cell surface proteins represent the common antigens of $V$. cholerae, CIE was done, using antisera to $V$. cholerae 395 (Ogawa, classical). Several immunoprecipitation lines were obtained from the homologous Ogawa 395 whole-cell sonicates. Whole-cell sonicates from heterologous strains such as 569B (Inaba, classical), W-13021 (Ogawa, El Tor) and N16961 (Inaba, El Tor) were also examined by CIE against antisera to the cell surface proteins 
Table 1. Agglutination and vibriocidal activities of antisera to $V$. cholerae cell surface proteins

Antisera were raised in rabbits against cell surface proteins from $V$. cholerae 395 (Ogawa, classical). The major cell surface protein $(48 \mathrm{kDa})$ was obtained from the polyacrylamide gel as described in the text. Each value is the arithmetic mean of duplicate determinations. Agglutination and vibriocidal activities were determined as described in the text.

Antibody titres to:

from strain Ogawa 395. Each sonicate produced several immunoprecipitation lines, suggesting that strain Ogawa 395 shared several protein antigens with strains belonging to both biotypes (classical and El Tor) and serotypes (Ogawa and Inaba). When whole cells were treated with proteinase $\mathbf{K}$, the majority of the precipitation lines disappeared, suggesting that most of the precipitation lines were due to proteins. Pre-immune rabbit sera did not produce any immunoprecipitation reaction.

\section{Biological activities of the antisera}

The biological properties of the antisera to the cell surface proteins as well as to the major $48 \mathrm{kDa}$ protein were examined by analysing their agglutinating and vibriocidal activities. Both the antisera agglutinated $V$. cholerae strains irrespective of their biotypes and serotypes. These sera also possessed complement-mediated vibriocidal activity against $V$. cholerae strains of all types (Table 1). Pre-immune rabbit sera had none of these activities.

\section{Intestinal immune responses to cell surface proteins}

Intestinal saline washings from four rabbits, immunized parenterally, were examined by ELISA. Immunoglobulins of both isotypes ( $\operatorname{IgA}$ and $\mathrm{IgG})$ to cell surface proteins were detected in the intestinal washings, the arithmetic mean of the end-point titres being 40 and 475 for $\operatorname{IgA}$ and IgG, respectively. When cell surface proteins were injected in combination with liposomes, comprising egg lecithin, cholesterol and phosphatidic acid, antibody titres increased significantly. The arithmetic means of the end-point titres for IgA and IgG antibodies in the intestinal fluids were 750 and 11000 , respectively. Very little antibody activity to the cell surface proteins was observed in the intestinal fluids of unimmunized rabbits.

\section{DISCUSSION}

In this investigation surface proteins were isolated by extracting $V$. cholerae cells with EDTA/ $\mathrm{NaCl}$. The outer membrane of Gram-negative bacteria is composed of polyanionic molecules such as LPS and proteins (Nikaido \& Nakae, 1979). Divalent cations neutralize or form bridges between the anionic groups, thereby stabilizing the outer membrane. When cells are treated with EDTA, these cations may be removed from the cell membrane and macromolecules such as proteins and LPS could be released into the media.

Use of radioiodinated protein $A$ as an immunoprobe demonstrated that cell surface proteins could be extracted with EDTA/ $\mathrm{NaCl}$ (Kabir, 1983b). There is now further evidence in support of these findings through immunoelectron microscopic techniques. Gold markers have been used to detect various components localized at the cell surface (Romano \& Romano, 1977; Polak \& Varndell, 1984). Protein A-gold particles as probes were used to demonstrate that EDTA/ $\mathrm{NaCl}$ had extracted proteins, which were localized on the cell surface of $V$. cholerae. 
A method to obtain a preparation enriched with the major surface protein $(48 \mathrm{kDa})$ of $V$. cholerae is described here. Proteins obtained by extraction with EDTA/ $\mathrm{NaCl}$ were further treated with DOC. This is a mild detergent having high micelle concentration and small micellar weights (Helenius et al., 1979), which can be easily removed by dialysis. Although DOC preferentially solubilized some of the cell surface proteins, the insoluble pellet was significantly enriched with the major outer membrane protein. The procedure described here is simple and does not involve lengthy operations.

$V$. cholerae has two serotypes (Ogawa and Inaba) and two biotypes (classical and El Tor). There are several surface proteins common among these types. CIE showed that the antisera to the cell surface proteins from one type (Ogawa, classical) produced immunoprecipitation reactions to the whole-cell sonicates from both the biotypes and the serotypes. Immunoelectron microscopic techniques showed that these proteins were exposed on the cell surfaces of both the biotypes and the serotypes.

The antisera to the cell surface proteins produced both agglutinating and complementmediated bactericidal activities towards $V$. cholerae strains of all types. These proteins were exposed on the cell surface. Therefore, it is possible that these proteins produced antibodies in the rabbit sera which had both agglutinating and vibriocidal activities. Immunoglobulins of both isotypes (IgA and IgG) were detected in the intestinal fluids of rabbits immunized parenterally with cell surface proteins. Keren et al. (1983) also observed the presence of significant quantities of both $\operatorname{IgG}$ and $\operatorname{IgA}$ antibodies in the intestinal secretions of rabbits immunized parenterally with Shigella flexneri cells.

Although liposomes have been widely used as immunological adjuvants towards protein antigens (Ryman \& Tyrrell, 1980), very few reports have appeared regarding their use to boost immune responses to bacterial surface proteins. High-titre antibodies to cell surface proteins were observed when liposomes containing cell surface proteins were administered. Liposomes have advantages over most other adjuvants because they consist of biodegradable materials of known and simple composition, which are immunologically inert.

At present there is a need for a safe cholera vaccine for human use, which produces immunities against all biotypes and serotypes of $V$. cholerae. Cholera is a toxin-mediated disease and recently non-toxigenic $V$. cholerae strains have been constructed by molecular genetic techniques (Kaper et al., 1984). Although the gene for cholera toxin had been deleted from such strains, mild to moderate diarrhoea still occurred when volunteers were fed these strains (Kaper et al., 1984). Illness may have occurred due to other poorly characterized toxins produced by the organisms (Sanyal et al., 1983). Therefore, non-living immunogens, lacking both enterotoxicity and pyrogenicity, may be explored as candidate vaccines against cholera. Cell surface proteins appear to fulfil the requirements of a good cholera vaccine. They lack endotoxic properties (Kabir \& Mann, 1980) and are here shown to produce antibodies in the sera as well as in the intestinal fluids. Both agglutinating and vibriocidal antibodies against all the biotypes and the serotypes of $V$. cholerae were detected.

The author was the recipient of a visiting fellowship from the Netherlands Organization for the Advancement of Pure Research (ZWO) which partly supported this work.

\section{REFERENCES}

AXELSEN, N. H. (1973). Intermediate gel in crossed and in fused rocket immunoelectrophoresis. A crossed immunoelectrophoresis with intermediate gel. Scandinavian Journal of Immunology 2 (Supplement), 7177.

FIELD, M. (1971). Intestinal secretion: effect of cyclic AMP and its role in cholera. New England Journal of Medicine 284, 1137-1144.

helenius, A., McCaslin, D. R., Fries, E. \& TanFORD, C. (1979). Properties of detergents. Methods in Enzymology 56, 734-749.

KABIR, S. (1980). Composition and immunochemical

properties of the outer membrane proteins of Vibrio cholerae. Journal of Bacteriology 144, 382-389.

KABIR, S. (1982). Characterization of the lipopolysaccharide from Vibrio cholerae 395 (Ogawa). Infection and Immunity 38, 1263-1272.

KABIR, S. (1983a). Immunochemical properties of the major outer membrane protein of Vibrio cholerae. Infection and Immunity 39, 452-455.

KABIR, S. (1983b). The serological properties of the cell surface proteins of Vibrio cholerae. Journal of General Microbiology 129, 2199-2206.

KABIR, S. \& MANN, P. (1980). Immunological proper- 
ties of the cell envelope components of Vibrio cholerae. Journal of General Microbiology 119, 517525.

Kaper, J. B., Lockman, H. A., Baldini, M. M. \& LEVINE, M. M. (1984). Recombinant nontoxigenic Vibrio cholerae strains as attenuated cholera vaccine candidates. Nature, London 308, 655-658.

Keren, D. F., SCott, P. J., MCDonald, R. A. \& WiaTRAK, M. (1983). Effect of parenteral immunization on the local immunoglobulin A response of the intestine to Shigellg flexneri antigens. Infection and Immunity 42, 202-207.

King, J. \& Laemmli, U. K. (1971). Polypeptides of the tail fibres of bacteriophage T4. Journal of Molecular Biology 62, 465-477.

Levine, M. M., Nalin, D. R., Craig, J. P., Hoover, D., Bergquist, E. J., Waterman, D., Holley, H. P., Hornick, R. B., Pierce, N. F. \& Libonati, J. P. (1979). Immunity to cholera in man: relative role of antibacterial versus antitoxic immunity. Transactions of the Royal Society of Tropical Medicine and Hygiene 73, 3-9.

Majumdar, A. S., Dutta, P., Dutta, D. \& Ghose, A. C. (1981). Antibacterial and antitoxin responses in the serum and milk of cholera patients. Infection and Immunity 32, 1-8.

NikaIDO, H. \& NAKaE, T. (1979). The outer membrane of gram-negative bacteria. Advances in Microbial Physiology 20, 163-250.

PolaK, J. M. \& VARndell, I. H. (1984). Immunolabelling for Electron Microscopy. Amsterdam: Elsevier.

Romano, E. L. \& Romano, M. (1977). Staphylococcal protein A bound to colloidal gold : a useful reagent to label antigen-antibody sites in electron microscopy. Immunochemistry 14, 711-715.

van Rooijen, N. \& van Nieuwmegen, R. (1980). Liposomes in immunology: evidence that their adjuvant effect results from surface exposure of the antigens. Cellular Immunology 49, 402-407.

RoTH, J. (1982). The preparation of protein A-gold complexes with $3 \mathrm{~nm}$ and $15 \mathrm{~nm}$ gold and their use in labelling multiple antigens on ultra-thin sections. Histochemical Journal 14, 791-801.

Ryman, B. E. \& Tyrrell, D. A. (1980). Liposomesbags of potential. In Essays in Biochemistry, pp. 49 98. Edited by P. N. Campbell \& R. D. Marshall. London: The Biochemical Society.

Sanyal, S. C., Alam, K., NeOgi, P. K. B., HuQ, M. I., Al-Mahmud, K. A. (1983). A new cholera toxin. Lancet $i, 1337$.

Slot, J. W. \& GeuZE, H. J. (1981). Sizing of protein Acolloidal gold probes for immunoelectron microscopy. Journal of Cell Biology 90, 533-536.

WEEKE, B. (1973). Crossed-immunoelectrophoresis. In A Manual of Quantitative Immunoelectrophoresis, $\mathrm{pp}$. 47-56. Edited by N. H. Axelsen, J. Kroll \& B. Weeke. Oslo: Universitetsforlaget.

WESTPHAL, O. \& JANN, K. (1965). Bacterial lipopolysaccharides. Methods in Carbohydrate Chemistry 5, 83-96.

WestPhal, O., LUderitz, O. \& Bister, F. (1952). Uber die Extraktion von Bakterien mit Phenol-wasser. Zietschrift für Naturforschung B7, 148-155. 